\title{
COMMENTS
}

\section{Voluntariness of Confessions in Habeas Corpus Proceedings: The Proper Standard for Appellate Review}

\author{
Keith R. Dolliver $\dagger$
}

The body of a young girl is found in a cemetery, her head crushed and much of her clothing removed. ${ }^{1}$ Two days later, police officers interview a suspect at the home he shares with his mother. The suspect agrees to accompany the officers to the station, where questioning begins after the police require the suspect to wait two hours in an office. Following extensive questioning, a police officer suggests that the suspect submit to a polygraph test, and the suspect agrees.

Upon completion of the initial polygraph test, the examiner informs the suspect that he has reason to believe that the suspect is lying and questions him further. At this point the suspect confesses orally to the murder. A police officer is brought into the room, and, after waiving a reading of the Miranda warnings, the suspect again confesses to the murder and signs a written statement indicating that he killed the girl by running over her with his car after she refused to have sex with him.

At trial, the defendant objects to the introduction of his written confession into evidence, alleging that the examiner lied about the results of the initial polygraph test to intimidate him into confessing to the murder. The trial court admits the written confes-

$\dagger$ B.A. 1985, Swarthmore College; J.D. Candidate 1990, The University of Chicago.

1 This set of facts is based on Sotelo $v$ Indiana State Prison, 850 F2d 1244, 1245-46 (7th Cir 1988). See also Sotelo v State of Indiana, 264 Ind 298, 342 NE2d 844 (1976). 
sion over the defendant's objections, and the defendant is convicted of first degree murder. On appeal to the state supreme court, both the verdict and the trial court's admission of the confession are affirmed.

Thirteen years later, the defendant files a petition for a writ of habeas corpus under 28 USC $\S 2254$ in federal district court. The district court, following the Supreme Court's decision in Miller $v$ Fenton, ${ }^{2}$ conducts a de novo review of the defendant's claim that his confession was involuntary. After this plenary review, the district court denies the petition. The defendant then appeals the dis: trict court's decision to the federal court of appeals. ${ }^{3}$

At this point, the court of appeals will probably follow the lead of the other circuits and conduct an additional de novo review. ${ }^{4}$ Like the other circuits, it will reason that the Supreme Court's decision in Miller $v$ Fenton requires both federal district courts and courts of appeals to conduct de novo review of the voluntariness of a confession when a habeas corpus petition claims that the state court admitted an improperly obtained confession into evidence.

Despite the unanimity of the circuits on this issue, it is doubtful that Miller does in fact mandate de novo review of the voluntariness issue in the federal appellate courts. Neither the rationale for de novo review of voluntariness at the district level, the objectives of $\S 2254$, nor the directives of Federal Rule of Civil Procedure 52(a), compels de novo review at the appellate level. In short, the appellate courts' interpretation of their role in reviewing the voluntariness question in habeas cases seems to "reflect[] neither the considerations motivating Miller nor those underlying the division of responsibilities between trial and appellate courts."

\footnotetext{
2474 US 104 (1985).

${ }^{3}$ So far there have been three separate judicial inquiries into the voluntariness of the defendant's confession: two by the state courts and one by the federal district court. See Sotelo, $850 \mathrm{~F} 2 \mathrm{~d}$ at $1246 \mathrm{n} 1$. States with intermediate appellate courts may provide three opportunities for such inquiry.

4 See Green v Scully, 850 F2d 894, 900 (2d Cir 1988); Miller v Fenton, 796 F2d 598, 601 (3d Cir 1986); United States v Hawkins, 823 F2d 1020, 1022-23 (7th Cir 1987); and United States $v$ Wauneka, 842 F2d 1083, 1087 (9th Cir 1988). But see Carr v Henderson, 385 F2d 531, 532 (6th Cir 1967) (voluntariness of a confession in habeas proceedings reviewed under the "clearly erroneous" standard). Note that Carr was decided eighteen years before the Supreme Court's decision in Miller.

${ }^{3}$ Sotelo v Indiana State Prison, 850 F2d 1244, 1253 (7th Cir 1988) (Easterbrook concurring). Judge Easterbrook's argument is based largely on the notion that appellate review of the voluntariness issue would be inefficient. Id at 1254. See also Wilson v O'Leary, No 892085, slip op at 8 (7th $\mathrm{Cir}$, February 7, 1990). Inefficiency has been frequently decried by the Supreme Court in other areas of appellate review of factual issues. See Anderson v Besse-
} 
This Comment argues thatthe Supreme Court has not mandated de novo appellate review of a district court's finding on the voluntariness of a confession. After reviewing the law of voluntariness of confessions and the federal habeas corpus statute, the Comment focuses on the case that seems most strongly to urge de novo appellate review, Miller $v$ Fenton. Because Miller was concerned not with ensuring de novo review of voluntariness generally, but with securing federal de novo review of this significant constitutional interest, district court de novo review seems sufficient. From this clarification of Miller, the Comment turns to an examination of the "constitutional fact" doctrine, on which Miller's holding may have been based. Concluding that this doctrine has been inconsistently applied by the Court and has rarely mandated review at all judicial levels, the Comment suggests that the constitutional fact doctrine does not control whether appellate courts must review the voluntariness question de novo. Instead, the appellate courts should treat district court findings on voluntariness as findings of fact under Federal Rule of Civil Procedure 52(a) and review them under the "clearly erroneous" standard.

Since the federal appellate courts are not required to conduct plenary review of the voluntariness issue under either the constitutional fact doctrine or Rule 52(a), any decision to conduct discretionary review should consider other factors that weigh against de novo review in habeas corpus cases. This Comment examines two such factors: efficiency concerns and the legislative history of the statute. Efficiency recommends that the courts of appeals avoid de novo review of voluntariness and rely instead on the de novo findings of the district courts, which are best suited and accustomed to such searching inquiries. The legislative history underlying the 1966 amendment to the habeas corpus statute, while not directly touching on the issue of appellate review, generally supports the efficiency argument. The purpose of that amendment was to ensure the efficient review of habeas corpus petitions in the federal courts. Thus, absent any mandate or other justification to conduct de novo review at the appellate level, the circuit courts' current commitment to de novo review is unwarranted and should be rejected in favor of review under the clearly erroneous standard. 


\section{Background: Voluntariness of Confessions and Habeas Corpus}

\section{A. The Voluntariness Test}

Whether upon direct appeal or review of a habeas corpus petition, the inquiry into the voluntariness of a confession is a notoriously difficult process. In Culombe $v$ Connecticut, ${ }^{6}$ the Supreme Court observed that the inquiry into the voluntariness of a confession involves several elements. First, the basic historical facts surrounding the confession at issue must be established. Second, the court must determine if the defendant's mental state was such that the decision to confess could be considered voluntary. Finally, the court must apply the proper legal rule to the findings reached in the previous steps to determine if the confession was voluntary for purposes of the Due Process Clause. ${ }^{7}$

The legal rule set forth in Culombe mandates a two-pronged judicial inquiry. The first prong requires the court to determine whether the confession was a product of the defendant's free will, or whether the defendant's will was "overborne" by law enforcement or other government officials. ${ }^{8}$ The second prong, accorded equal weight by the Court, asks whether the system of interrogation employed by the State is "so inherently coercive that its very existence is irreconcilable with the possession of mental freedom by a lone suspect," regardless of whether there is reason to believe that the defendant's will was in fact overborne. ${ }^{9}$ Confessions must therefore meet both conditions or be found to violate the defendant's Fourteenth Amendment due process rights.

The voluntariness test set forth by the Supreme Court requires an extensive investigation of factual issues concerning both the defendant's mental state and the methods used by law enforcement officials to extract the confession. ${ }^{10}$ Courts making a

- 367 US 568 (1961).

7 Id at 603. The standard of voluntariness is a question of law, and hence reviewable de novo under Rule 52(a). See text at note 96.

${ }^{8}$ Id at 602 .

- Gallegos v Colorado, 370 US 49, 52 (1962) (quoting Ashcraft $v$ Tennessee, 322 US 143,154 (1944)).

${ }^{10}$ In Miranda $v$ State of Arizona, 384 US 436, $478-79$ (1966), the Court took a step toward simplifying this "hybrid" voluntariness test, holding that if police failed to fully inform a suspect both of his right to remain silent and his right to counsel, the courts were to conclude that the confession was involuntary and bar its admission into evidence. Yet the Court failed to make a complete break with the traditional voluntariness test, stating that even if the police had given the new Miranda warnings, lower courts could still find the confession involuntary under the old "due process" test of Culombe. Miranda, 384 US at 
voluntariness finding are thus required to expend significant resources reviewing the factual record surrounding the confession and determining whether the defendant's confession should be admitted as a voluntary, self-incriminating statement. That trial courts must make this investment is undisputed. Whether federal appellate courts must also engage in this complex inquiry depends upon the appropriate standard of review of lower court findings on voluntariness.

\section{B. Appellate Review of Voluntariness}

While the Supreme Court has established this two-pronged voluntariness test for the lower courts, it has never clarified how appellate courts should treat findings made by trial courts under the test. A factor undoubtedly clouding the appellate courts' understanding of their responsibilities is that the Supreme Court itself has conducted de novo review of voluntariness in a good number of cases. Many in the string of confession cases culminating in Miranda $v$ Arizona ${ }^{11}$ involved de novo review of confessions, ${ }^{12}$ and Miranda itself can be understood as an effort by the Court to develop a clear rule that would free it from case-by-case determinations of voluntariness. ${ }^{13}$

Yet in holding that it was free to subject state court findings on the voluntariness of confessions to plenary review in both direct appeals from state courts and in habeas proceedings, the Court did not determine what standard is appropriate for circuit courts reviewing federal district court findings. The failure of the Court to clarify this issue may have resulted from a number of factors. It is apparent from a review of the factual circumstances of the Court's

476. Indeed, to the extent that law enforcement officials use the Miranda warnings as standard procedure, lower courts will frequently resort to the traditional voluntariness test. Moreover, in post-Miranda decisions, the Court has retreated from the position that the absence of the Miranda warnings would constitute conclusive proof that a defendant's confession was involuntary. See Michigan v Tucker, 417 US 433 (1974); New York v Quarles, 467 US 649 (1984); and Oregon v Elstad, 470 US 298 (1985). Thus, both because the police now routinely give Miranda warnings, and because the absence of such warnings is not conclusive proof of involuntariness, the courts have been forced back to the clumsy "due process" voluntariness test. As the Supreme Court itself has noted, "the Court has continued to measure confessions against the requirements of due process." Miller, 474 US at 110.

11384 US 436 (1966).

12 See, for example, Haynes v State of Washington, 373 US 503 (1963).

13 See Stephen J. Schulhofer, Confessions and the Court, 79 Mich L Rev 865, 869-70 (1981) (noting among the difficulties of the pre-Miranda regime that "when higher courts did attempt to address confessions questions, they found themselves so wholly at sea that the appearance of principled judicial decision-making inevitably suffered, whether or not they chose to hold the confession inadmissible"). 
pre-Miranda confession cases that state courts had upheld convictions based on confessions obtained through plainly egregious law enforcement practices, methods which might well be considered physical and mental torture. ${ }^{14}$ As a result, the Court was primarily concerned with establishing a baseline constitutional standard for state law enforcement methods. The Court was therefore interested in ensuring plenary federal review of state court findings on this important constitutional issue, not in determining how federal district court findings should be treated by the federal appellate courts. ${ }^{15}$ In fact, most cases discussing the importance of federal review of voluntariness of confessions were taken directly from state supreme courts on writs of certiorari, and as a result the Supreme Court was the only federal court to consider the voluntariness issue. Thus, the allocation of adjudicative authority within the federal system was not at issue. ${ }^{16}$ Neither was the efficient processing of habeas petitions by the federal courts at issue, since the Court had not yet experienced the "explosion" of habeas corpus petitions that occurred in the 1960s. ${ }^{17}$ Moreover, as discussed in section III, the Court's decision to use its discretion to review findings of fact related to constitutional rights does not automatically indicate a mandate to the circuit courts to do the same.

The Supreme Court, then, has sanctioned de novo review by at least one federal court of state court findings on the voluntariness question. Yet, as will be shown in section II, the Court has not mandated that federal appellate courts conduct de novo review of district court findings on voluntariness. The de novo standard may be appropriate for federal review of state court decisions, but it does not follow that federal appellate courts are also bound to it once the need for independent federal review has been satisfied.

\section{The Habeas Corpus Statute}

The writ of habeas corpus-the "Great Writ"18_-lies at the core of American notions of liberty and due process. The Framers

\footnotetext{
${ }^{14}$ See, for example, Watts $v$ Indiana, 338 US 49, $52-53$ (1949) (suspect kept in solitary confinement for six days with no place to sit or sleep except the floor, and purposely denied sleep by extensive police interrogation).

${ }^{15}$ See Ashcraft, 322 US at 155 ("The Constitution stands as a bar against the conviction of any individual in an American court by means of a coerced confession."). See also Watts, 338 US at 55.

${ }^{16}$ See, for example, Watts, 338 US at 50; Culombe, 367 US at 570.

17 On this growth, see text at note 98 .

${ }^{18}$ See, for example, Pennsylvania Bureau of Correction v United States Marshals Service, 474 US 34, 39 n 5 (1985).
} 
of the Constitution affirmed its sanctity by requiring that Congress provide a means by which citizens could avail themselves of it in the federal courts. ${ }^{19}$ The writ as we know it today has its origins in the Habeas Corpus Act of 1867 ("the Act"), which explicitly authorized the federal courts to issue writs of habeas corpus "in all cases where any person may be restrained of his or her liberty in violation of the Constitution, or of any treaty or law of the United States." 20 Additionally, the Act empowered a federal court reviewing a habeas corpus petition to disregard the conclusions of the state court and take testimony and determine the facts of the case for itself. ${ }^{21}$

The current federal habeas statute, 28 USC $\S 2254$, grants the federal courts authority to review petitions for the writ of habeas corpus from "person(s) in custody pursuant to the judgment of a State court only on the ground that he is in custody in violation of the Constitution or laws or treaties of the United States."22 The statute further provides that habeas corpus petitions shall not be granted unless it appears that the applicant has exhausted all remedies available in the state courts, or evidence exists either of an absence of appeal procedures, or that such procedures would for some reason be ineffective to protect the rights of the petitioner. ${ }^{23}$ Thus, federal courts cannot intervene to correct state court actions until the state's judicial system has had a full opportunity to consider and correct any flaws.

Requiring exhaustion of state remedies is not the only method by which Congress has sought to limit federal review of state court proceedings. Significant concern arose in the 1960s that the writ's importance and legitimacy would be diluted through abuse. In 1966, Congress responded to this sentiment by adding a new subsection to the habeas corpus statute:

[A] determination after a hearing on the merits of a factual issue, made by a State court of competent jurisdiction in a

\footnotetext{
29 "The privilege of the Writ of Habeas Corpus shall not be suspended, unless when in Cases of Rebellion or Invasion the public safety may require it." US Const, Art I, § 9, cl 2. See also Ex Parte Bollman, 8 US (4 Cranch) 75 (1807).

2014 Stat 385,385 (1867). The availability of the federal writ to state prisoners did not fully develop until the middle of the nineteenth century. Prior to the 1867 act, Congress had twice passed legislation giving the federal courts the authority in particular situations to exert jurisdiction by writ of habeas corpus over prisoners held by the states. See 4 Stat 633 , 634 (1833) (habeas corpus for citizens confined by state for acts taken in pursuance of federal law); 5 Stat 539 (1842) (habeas corpus for foreign nationals held by state or federal government).

21 14 Stat 385, 386 (1867).

2228 USC \& 2254(a) (1982).

${ }^{23} 28$ USC \& 2254(b) (1982).
} 
proceeding to which the applicant for the writ [of habeas corpus] and the State ... were parties, evidenced by a written finding, written opinion, or other reliable and adequate written indicia, shall be presumed to be correct. . . ${ }^{24}$

Thus, with certain exceptions noted in the statute, ${ }^{25}$ the federal courts must presume that state court findings of fact are correct.

Congress's amendment to the Act accorded with prior Supreme Court reasoning. Just three years before the amendment, in Townsend $v$ Sain, the Court had established the principle that federal courts should presume the correctness of state court findings on factual issues. ${ }^{26}$ In that case, the Court found that the state court had failed to compile a record adequate to support its finding that the confession at issue was voluntary; however, the Court observed that when a habeas corpus applicant had been afforded a full and fair hearing in the state court, the federal courts should ordinarily "accept the facts found" in the state proceeding. ${ }^{27}$ It is clear that Congress recognized the benefits of this view and thus simply chose to "elevate[] [the Court's] exhortation into a mandatory presumption of correctness." ${ }^{28}$

\section{Miller v Fenton and Federal Appellate Review of VOLUNTARINESS}

Although in $\S 2254$ (d) Congress directed the federal courts to accept findings of fact made by the state courts, it did not clarify which aspects of a state court finding are "fact" and which are "law" for purposes of the statute. ${ }^{29}$ Thus, the statute did not make

${ }^{24}$ Pub L No 89-711, 80 Stat 1105 (1966), codified at 28 USC § 2254(d) (1982).

${ }^{25}$ The eight exceptions are: (1) the merits of the case were not resolved in the state proceeding; (2) the state court's fact-finding procedure was flawed; (3) material facts were not adequately developed in the state hearing; (4) the state court lacked jurisdiction; (5) the state failed to appoint counsel for an indigent petitioner; (6) the applicant did not receive a full, fair hearing; (7) the applicant was otherwise denied due process; or (8) the record does not fairly support the finding of the state court. 28 USC § 2254(d) (1)-(8).

${ }^{26} 372$ US 293, 318 (1963). The Court recognized that this portion of the federal habeas corpus statute was taken from Townsend. See Miller, 474 US at 111.

27 Townsend, $372 \mathrm{US}$ at 318.

${ }^{28}$ Miller, 474 US at 111-12.

${ }^{28}$ Prior to its decision in Miller, the Court had on a number of occasions upheld the application of the $\S 2254$ (d) presumption of correctness to findings reached by the state courts. See, for example, the following cases cited in Miller, 474 US at 112-13: Wainwright $v$ Witt, 469 US 412, 426-30 (1985) (trial court determination that a prospective juror in a capital case was properly excluded); Patton $v$ Yount, 467 US 1025, 1036-40 (1984) (impartiality of an individual juror); Rushen $v$ Spain, 464 US 114, 120 (1983) (effect of ex 
clear how a court should categorize a state court's finding on the voluntariness of a confession. That question was presented in Miller $v$ Fenton. In Miller, the Third Circuit had affirmed a district court's denial of a petition for habeas corpus by a man convicted of murder in a New Jersey state court. At his trial, the defendant had moved to exclude evidence of his confession on the theory that his confession had been coerced. ${ }^{30}$ The trial court rejected the defendant's motion, and its decision was ultimately upheld by the New Jersey Supreme Court. The defendant then sought a writ of habeas corpus in federal district court, but the court dismissed the application. The Third Circuit affirmed. Both courts held that the issue of voluntariness was a question of fact under 28 USC § 2254(d) and that the federal inquiry was "limited to determining whether the state court applied the proper legal test, and whether [its] factual conclusions ... [were] supported on the record as a whole."

On certiorari, the Supreme Court rejected this reading of the statute, holding that the state court finding on the voluntariness of a confession was not a finding of fact entitled to deference under the federal habeas corpus statute. The Court reasoned that the issues raised in an involuntary confession claim pose important due process concerns, ${ }^{32}$ and concluded that "the ultimate question whether ... the challenged confession was obtained in a manner compatible with the requirements of the Constitution is a matter for independent federal determination." 33

At no point in its opinion did the Court address whether a federal appellate court should defer to a federal district court's findings on that issue. Rather, it based its decision on the need for an "independent federal determination" of issues, like voluntariness, that are intertwined with the constitutional due process rights guaranteed against the states through the Fourteenth Amendment. As the Court stated at the close of its opinion:

parte communication on impartiality of individual juror); Maggio $v$ Fulford, 462 US 111, 113 (1983) (competency to stand trial); Marshall v Lonberger, 459 US 422, 432-35 (1983) (determination that defendant received and understood sufficient notice of charges against him to render guilty plea voluntary).

so Miller, 474 US at 108. The defendant claimed that the police officers had lied when interrogating him-telling him that he had been identified as the assailant by the victim and others-and had sought to gain his confidence by telling him that they didn't believe he was a "criminal" and that he needed psychological help, not punishment. Id at 106-07.

s1 Miller, 741 F2d 1456, 1462 (3d Cir 1984), rev'd and remanded, 474 US 104 (1985).

${ }^{32}$ Miller, 474 US at 109-16.

33 Id at 112 (emphasis added). 
We reiterate our confidence that state judges, no less than their federal counterparts, will properly discharge their duty to protect the constitutional rights of criminal defendants. We note only that in the confession context, independent federal review had traditionally played an important parallel role in protecting the rights at stake when the prosecution secures a conviction through the defendant's own admissions. ${ }^{34}$

In considering the precedential force of the Court's opinion in Miller, it is important to keep in mind the specific question at issue in the case. Because the district court and the Third Circuit had both deferred to the state court's finding, no federal court had considered the constitutional questions raised by the petitioner's involuntary confession claim by the time the case reached the Supreme Court. The Court's emphasis, then, was on establishing that the federal courts as a body should not defer to state court findings on voluntariness of confessions, given the long-standing federal interest in the voluntariness question. ${ }^{35}$

In considering the voluntariness of confessions, the Court has sought to protect criminal defendants from two related evils: abusive law enforcement methods that undermine their due process rights and criminal justice systems that deny their free will. Miller's guarantee of de novo review in a federal forum alleviates these concerns by providing independent protection to constitutional rights.

But in order for the Supreme Court to permit federal courts to disregard state court findings, it had to circumvent the troublesome problem that its own jurisprudence and 28 USC $\S 2254$ (d) required federal court deference to state court findings of fact. The solution, a semantic one, was to conclude that voluntariness was not a "fact" under the statute.

In interpreting the statute, the Court found that it should be construed in light of the Court's prior holding in Townsend $v$ Sain, from which Congress had drawn the language of $\S 2254(\mathrm{~d})$. In Townsend, the Court had made a distinction between ordinary facts and the "ultimate constitutional question" of whether a confession was voluntary. ${ }^{38}$ The Miller Court held that this distinction was inherent in the statute, and that $\$ 2254(\mathrm{~d})$ incorporated the holding in Townsend and other cases that "the ultimate question

\footnotetext{
34 Id at $117-18$.

${ }^{35}$ See Sotelo, 850 F2d at 1254 (Easterbrook concurring).

${ }^{36}$ Townsend, 372 US at $309 \& \mathrm{n} 6$.
} 
of the admissibility of a confession merits treatment as a legal inquiry requiring plenary federal review."37

The circuit courts have read Miller to hold that a court's findings on the voluntariness of a confession, given the constitutional issues involved, are not ordinary findings of fact, but are of special importance and merit "independent consideration in a federal habeas corpus proceeding." dent inquiry into district court findings on voluntariness. Yet even if we accept that the Court has drawn a distinction between ordinary factual issues and "ultimate constitutional questions," it is not clear that this distinction requires federal appellate courts to conduct de novo review of district court findings of the latter sort.

\section{The Constitutional Fact Doctrine and Appellate Review}

\section{A. The Constitutional Fact Doctrine}

If the circuit courts of appeals are correct in binding themselves to de novo review of district court findings on voluntariness, one justification that leaps to mind immediately is the "constitutional fact" doctrine. ${ }^{39}$ The foremost example of the doctrine is Bose Corp. $v$ Consumers Union of United States, Inc., ${ }^{40}$ where the Court stated that the First Amendment principles at issue in a defamation action brought in federal district court required both the appellate court and the Supreme Court to conduct de novo review of the district court's finding as to "actual malice." Although malice was admittedly a question of fact, the Court found that "the clearly-erroneous standard of Rule 52(a) ... does not prescribe the standard of review to be applied in reviewing a determination of actual malice."11 Because a finding of "actual malice" involves constitutional principles, the Court held that reviewing courts had to give plenary consideration to the issue. ${ }^{42}$

Miller, 474 US at 115.

38 Id.

3* The Court's opinion in Miller v Fenton does not invoke the "constitutional fact" doctrine as a basis of its decision; thus, the Court has never explicitly stated that the doctrine applies to review of district court findings on the voluntariness of confessions. This may, however, have more to do with the fact that Justice O'Connor, who joined in Justice Rehnquist's dissent in Bose Corp. $v$ Consumers Union of United States, Inc., 466 US 485 (1984) (see text at note 44), authored the majority opinion in Miller than with any specific desire of the Court to avoid designating the voluntariness of confessions a "constitutional fact."

10466 US 485 (1984).

41 Id at 514.

${ }^{42}$ The Court made similar distinctions between "ordinary" and "constitutional" facts 
The "constitutional fact" doctrine has been sharply criticized as an improvident attempt by the Court to ensure accuracy in the determination of constitutional rights without recognizing the enormous potential strain the doctrine could place on judicial resources. ${ }^{43}$ Perhaps the strongest critique of the doctrine has come from Chief Justice Rehnquist, who dissented in Bose Corp. While accepting the majority's claims that First Amendment rights needed careful protection, then-Justice Rehnquist argued:

Because it is not clear to me that the de novo findings of appellate courts ... are likely to be any more reliable than the findings reached by trial judges, I cannot join the majority's sanctioning of factual second-guessing by appellate courts. I believe that the primary result of the Court's holding today will not be greater protection for First Amendment values, but rather only lessened confidence in the judgments of lower courts and more entirely factbound appeals. ${ }^{44}$

The application of the constitutional fact doctrine to issues beyond those involved in Bose Corp. remains unclear. The Court has come nowhere near requiring de novo review for all lower court findings involving constitutional rights. Indeed, whereas the Court held in Bose Corp. that the importance of the First Amendment required the federal appellate courts to review de novo lower court findings of actual malice, ${ }^{46}$ the Court appears to have rejected the "constitutional fact" doctrine in another important area of First Amendment law, holding that the adjudicative authority to determine obscenity must be left with the trial courts. ${ }^{46}$

Other constitutional rights have been excepted altogether from this special review. In Illinois $v$ Gates, ${ }^{47}$ for example, the Court observed that Fourth Amendment protections against unreasonable search and seizure did not require the Court to conduct

\footnotetext{
in cases pre-dating Bose Corp., holding that plenary appellate review of such constitutional facts is appropriate. See, for example, Cox $v$ Louisiana, 379 US 536, 545 n 8 (1965) (quoting Edwards v South Carolina, 372 US 229, 235 (1963)) (finding a "duty . . to make an independent examination of the whole record" where petitioner's First Amendment rights had allegedly been infringed by conviction for breach of the peace); Ohio Valley Water Co. $v$ Ben Avon Borough, 253 US 287 (1920) (Court possesses authority to review for itself utility rates set by state ratemaking agency where claim is raised that such rates are confiscatory).

${ }^{43}$ See generally, Henry P. Monaghan, Constitutional Fact Review, 85 Colum L Rev 229, 264-76 (1985); Frank R. Strong, Dilemmic Aspects of the Doctrine of "Constitutional Fact", 47 NC L Rev 311 (1969).

4 Bose Corp., 466 US at 520 (Rehnquist dissenting).

15 Bose Corp., 466 US at 514.

${ }^{48}$ Miller v California, 413 US 15, 24-25 (1973).

4762 US 213 (1983).
} 
a de novo review of a magistrate's determination that probable cause existed for a police search. Declaring that reviewing courts must uphold the magistrate's probable cause determination if there is a "substantial basis" for that conclusion, the Court recognized that de novo review would likely result in police officials turning away from the warrant procedure as the reviewing courts set aside magistrates' determinations. ${ }^{48}$

Likewise, in Dayton Board of Education v Brinkman, ${ }^{49}$ the Court approved a decision by the Sixth Circuit Court of Appeals to review under the "clearly erroneous" standard the district court's finding on whether a school district had engaged in purposeful segregation in violation of the Equal Protection Clause of the Fourteenth Amendment. Thus, the Court appears to believe that the mere presence of significant constitutional issues in Fourteenth Amendment equal protection cases does not necessarily mandate de novo review..$^{\text {so }}$

The Court also rejected de novo review in favor of the "clearly erroneous" standard in Container Corp. of America v Franchise Tax Board.51 The Court held that the federal appellate courts should defer to state court findings that an enterprise constitutes a unitary business, despite the fact that this determination was bound up in an interpretation of the limits imposed by the Commerce Clause on a state's power of taxation. The Court recognized the problems of de novo review of a state court's finding: "It will do the cause of legal certainty little good if this Court turns every colorable claim that a state court erred ... into a de novo adjudication, whose unintended nuances would then spawn further litigation and an avalanche of critical comment." 52

\section{B. Voluntariness of Confessions as a Constitutional Fact}

The Court, then, has failed to provide a rational basis for distinguishing between "constitutional facts" that merit plenary federal appellate review and those that do not, ${ }^{53}$ making it quite diffi-

48 Id at 236-37.

443 US 526 (1979).

${ }^{\text {Bo }}$ See id at 534 .

${ }^{51} 463$ US 159 (1983).

${ }^{52}$ Id at 176 (footnotes omitted).

${ }^{3 s}$ Most commentators who have sought to explain the Court's seemingly inconsistent rulings have simply thrown up their hands. See Frank R. Strong, The Persistent Doctrine of "Constitutional Fact," 46 NC L Rev 223, 282-83 (1968); and Monaghan, 85 Colum L Rev at 264-71 (cited in note 43). Monaghan has suggested that the seemingly ad hoc basis upon which the Court applies the constitutional fact doctrine supports discretionary de novo re- 
cult to determine what standard of review to apply to district court determinations of the voluntariness of a confession.

In a widely cited article, Professor Henry Monaghan has formulated a theory of constitutional fact review that might provide guidance regarding the applicability of the doctrine in the voluntariness context. Professor Monaghan argues that plenary federal appellate review of constitutional facts makes sense in only two situations. The first is where there is "a need to guard against systemic bias brought about or threatened by other actors in the judicial system." $"$ This might explain why the Court has authorized plenary review of state court findings on voluntariness, since the Court was legitimately concerned that state courts would have improper incentives to uphold traditional law enforcement methods against constitutional challenge. ${ }^{\mathrm{s5}}$

Second, constitutional fact review is properly conducted where there is a "perceived need for case-by-case development of constitutional norms." ${ }^{156}$ For Professor Monaghan, this justification is exemplified when the Court makes an independent review of the record to more fully elaborate a constitutional standard such as the reasonableness of a warrantless search under the Fourth Amendment. ${ }^{57}$ Professor Monaghan concludes, however, that both justifications can be met by plenary appellate review on a discretionary rather than mandatory basis, arguing that Bose Corp. should be viewed as an aberration in its announcement of mandatory appellate court review of district court findings of constitutional facts. ${ }^{58}$

view of constitutional facts by the Supreme Court and the federal circuit courts. Declaring that the discretion to conduct an independent review of certain factual findings is essential in shaping the outlines of a constitutional issue, he states: "the perceived need for case-bycase development of constitutional norms is likely to be the single most important trigger for constitutional fact review.... [N]orm elaboration occurs best when the Court has power to consider fully a series of closely related situations involving a claim of constitutional privilege." Monaghan, 85 Colum $L$ Rev at 273 (cited in note 43).

This justification for the Court's apparent inconsistency in applying the "constitutional fact" doctrine fails, however, to provide an adequate explanation of the actual cases. It does not demonstrate how First Amendment protection of speech requires de novo review, while important findings of fact involving the Fourth Amendment, on the other hand, do not. Nor does the theory find any support in the Court's decisions themselves, which instead look to issues such as the historical treatment of the constitutional fact by the appellate courts, see Bose Corp., 466 US at 510, and whether de novo review at the appellate level comports with the relative expertise of judicial actors. See Miller, 474 US at 144.

54 Monaghan, 85 Colum L Rev at 272 (cited in note 43).

ss Id.

${ }^{86}$ Id at 273.

s7 Id at 273-75.

${ }^{38}$ Id at $264-71$. 
Thus, under Professor Monaghan's analysis, it is at the very least arguable that if the constitutional fact doctrine applies to the voluntariness of confessions, the appellate courts have discretion to conduct de novo constitutional review; the Supreme Court has not expressly required them to do so. Given Professor Monaghan's justifications for the doctrine, however, there seems to be no reason for appellate courts to apply the doctrine to review de novo district court findings of voluntariness in habeas corpus proceedings at all. First, there is no reason to suspect that the federal district courts suffer from some improper bias that will lead to a distortion of a federal right. Indeed, the Court has been content to entrust district courts with the responsibility of determining many issues of constitutional importance. ${ }^{59}$ Nor would it appear that the contours of the protection against the admission of involuntary confessions are so vague as to require "case-by-case norm elaboration." Although there perhaps was such a need when the Court itself established constitutional baselines for state law enforcement methods, there does not appear to be any present benefit from federal appellate courts "second-guessing" district court findings on voluntariness.

Thus, the constitutional fact doctrine does not support the circuit courts of appeals that feel compelled to conduct de novo review of district court findings on the voluntariness of confessions. At best, the doctrine might support discretionary use of the de novo standard, and even this argument is not self-evident.

\section{Appellate Review of Voluntariness Under Rule 52}

\section{A. Fact, Law, and Confessions}

If the constitutional fact doctrine does not mandate de novo review of voluntariness at the appellate level, courts are thrown back to a more conventional analysis of the standard of appellate review. Central to this analysis, of course, is Federal Rule of Civil Procedure 52(a): "Findings of fact, whether based on oral or documentary evidence, shall not be set aside unless clearly erroneous .... Thus, in reviewing findings of fact reached by the district courts, the circuit courts of appeals are bound to a narrow scope of review and may set aside such findings only when they are clearly erroneous or not supported by the evidence. ${ }^{60}$ Findings of

See text at notes $46-52$.

- See Martin B. Louis, Allocating Adjudicative Decision Making Authority Between the Trial and Appellate Levels: A Unified View of the Scope of Review, the Judge/Jury Question, and Procedural Discretion, 64 NC L Rev 993, 998-1002 (1986). 
law, however, are ordinarily reviewed without deference on appeal. ${ }^{61}$ In order to determine whether the appellate courts must conduct de novo review of a district court finding on the voluntariness of a petitioner's confession under Rule 52, one must decide if the district court's findings on voluntariness should be treated as a finding of fact or a finding of law.

The Supreme Court's decision in Miller sheds little light on this question. While the Court identified the state court finding on voluntariness as a "legal inquiry requiring plenary federal review," ${ }^{2}$ it did not state explicitly that a district court finding on this issue must be treated as a finding of law under Rule 52(a). Indeed, the Court limited its decision to the specific question at issue-whether state court findings on the voluntariness of a confession should be treated with deference by a reviewing federal court. $^{63}$ The basis for requiring federal review of the voluntariness of confessions appears to be not so much the notion that voluntariness is a "legal" issue requiring appellate review, but that (as we have seen above) the question involves federal rights uniquely susceptible to abuse by the states, meriting special scrutiny by the federal courts. Yet once the need for federal review has been satisfied at the district court level, de novo review by subsequent courts is not justifiable. Moreover, when we compare a district court's de novo review of the voluntariness of a confession to other similar kinds of inquiries, we see that there is no reason to categorize the finding as anything other than a finding of "fact."

The Court has recognized that the voluntariness of a confession is in part a " 'psychological' fact"64 requiring investigation into the mental state of the party who allegedly confessed voluntarily. Thus, the inquiry into voluntariness requires the factfinder to review the factual circumstances surrounding the defendant's decision to confess in order to determine whether the defendant confessed voluntarily. The Supreme Court has designated such investigations into an individual's state of mind as "factual" in other settings. ${ }^{65}$ Moreover, the Court has indicated that such in-

61 Id. See also Charles Alan Wright and Arthur Miller, Federal Practice and Procedure, $\S 2588$ at 750 (West, 1971) ("[Rule 516)] is silent about legal conclusions. This silence has been correctly interpreted as meaning that the 'clearly erroneous' instruction is not applicable and that the trial court's rulings on questions of law are reviewable without any such limitation."); United States v Mississippi Valley Generating Co., 364 US 520, 526 (1961).

${ }^{62}$ Miller, 474 US at 115.

See text at notes 29-37.

B4 Culombe, 367 US at 603.

6s See, for example, Dayton Board of Education v Brinkman, 443 US 526, 534 (1979) 
quiries are most appropriately left to the lower courts, with the appellate court conducting its own plenary review of the matter only in the event that the lower court's finding is clearly erroneous.

In Commissioner $v$ Duberstein ${ }^{66}$ for example, the Court held that the U.S. Tax Court's finding that a specific transaction was a "gift" turned on motive and intent; the appellate court should thus treat the finding as one of fact and review it under the "clearly erroneous" standard. The Court observed:

The nontechnical nature of the statutory standard, the close relationship of it to the data of practical human experience, and the multiplicity of relevant factual elements, with their various combinations, creating the necessity of ascribing the proper force to each, confirm us in our conclusion that primary weight in this area must be given to the conclusions of the trier of fact. ${ }^{67}$

On the other hand, the Court has observed that the inquiry into the voluntariness of a defendant's confession is not limited to an investigation of the defendant's state of mind at the time of the confession, but also requires the courts to examine the conditions surrounding the defendant's confession. In particular, courts must consider the methods used to extract the confession to determine whether, under such conditions, a confession could ever be considered voluntary. ${ }^{68}$ While this requirement "militates against treating the question as one of simple historical fact," essarily force the inquiry into the "law" category.

The Supreme Court has often held that the characterization of a collectivity of historical facts should be treated as a finding of fact for purposes of Rule 52(a). Thus, in Pullman-Standard $v$ Swint, ${ }^{70}$ the Court found that a district court's finding as to the defendant's discrimination against the plaintiffs was a finding of

(question of purposeful segregation left to trial court); Schneckloth $v$ Bustamonte, 412 US 218, 248-49 (1973) (question of voluntariness of consent to search left to trial court).

${ }^{\circ 6} 363$ US 278 (1960).

${ }^{67}$ Id at 289. The Court found that the U.S. Tax Court's expertise also supported giving that court primary responsibility for characterizing a transaction as a "gift". Id at 291. A similar argument might support leaving the question of voluntariness with the district courts, since they have experience and expertise in "psychological" issues (i.e., mens rea in criminal cases), both in instructing juries and in making such findings themselves in bench trials.

${ }^{68}$ Miller, 474 US at 116.

Id.

70 456 US 273 (1982). 
fact, subject to review under the "clearly erroneous" standard. ${ }^{71}$ While the Court characterized the question of whether the defendant's actions constituted discrimination as one of "pure[] fact," it is simply not a "fact" in the common understanding of that term. The district court's finding on the question of discrimination is a "conclusion at the end of a chain including historical facts and inferences, culminating in a characterization shaped by a rule of law."73 In considering whether a defendant has discriminated, or whether a defendant's behavior is "reasonable," nounce the proper rule of law and apply the facts to that rule. As one circuit court has noted, "[t] he question whether a rule of law has been violated-a question that requires applying the rule to the facts-is normally treated as a question of fact, ... not because it is a question of fact (it isn't) but as a way of expressing a decision to leave the answer to the trial judge or jury to make, subject only to limited appellate review."75

The district courts are particularly suited to determine the voluntariness of a confession, since they are familiar both with the process of making such determinations and with the applicable constitutional principles. The Supreme Court has recognized on many occasions the primary responsibility of the district courts in making such factual determinations, even when this process goes beyond simple findings about historical events, and has therefore classified these findings as "facts" for the purpose of Rule 52(a). ${ }^{76}$

But our analysis of whether these findings are "facts" cannot end here. The circuit courts' adoption of a de novo standard of review might be supported by language in Strickland $v$ Washington. ${ }^{77}$ In Strickland, the Court considered an appeal from a denial of a habeas corpus petition that contained claims of ineffectiveness of the petitioner's counsel at trial. The Court reasoned:

Although state court findings of fact made in the course of deciding an ineffectiveness claim are subject to the deference

71 Id at 287-88. See also Icicle Seafoods, Inc. $v$ Worthington, 475 US 709, 714 (1986) (question of whether an individual falls into the statutory definition of a "seaman" is a question of fact, reviewable under the "clearly erroneous" standard).

22 Pullman-Standard, 456 US at 288.

73 Sotelo, 850 F2d at 1254 (Easterbrook concurring).

74 Monaghan, 85 Colum $\mathrm{L}$ Rev at $234 \mathrm{n} 33$ (cited in note 43).

75 Davenport v DeRobertis, 844 F2d 1310, 1311-12 (7th Cir 1988) (emphasis in original). See also Sotelo, 850 F2d at 1254-55 (Easterbrook concurring).

${ }^{38}$ See, for example, Pullman-Standard $v$ Swint, 456 US 273 (1982); Duberstein v United States, 363 US 278 (1960); Illinois v Gates, 462 US 213 (1983).

77466 US 668 (1984). 
requirement of $\S 2254(\mathrm{~d})$, and although district court findings are subject to the clearly erroneous standard of Federal Rule of Civil Procedure 52(a), both the performance and prejudice components of the ineffectiveness inquiry are mixed questions of law and fact. ${ }^{28}$

One could infer from the Court's language that, in habeas cases, the relationship of the federal appellate courts to the federal district courts under Rule 52(a) must parallel the relationship of the federal district courts to the state courts under $\S 2254(\mathrm{~d})$. In other words, what is reviewable as a "mixed question of law and fact" under $\S 2254$ (d) should also be reviewable de novo by a federal appellate court under Rule 52(a). ${ }^{79}$ However, the question in Strickland, like that in Miller, was the appropriate level of deference to state court findings by the federal courts, not the deference due the district courts by the federal appellate courts.

Judge Posner, for one, has challenged the suggestion that categories of "law" and "fact" are identical under Rule 52(a) and $\$ 2254(\mathrm{~d})$. He argues that designations of "law" and "fact" by courts are not fixed, pre-existing categories, but are the product of "policy-grounded legal conclusions." the district courts must treat state court findings on the voluntariness of a defendant's confession as a finding of law under $\S$ 2254(d), and hence give it plenary review, Judge Posner states:

For purposes of appellate review, however, the issue might be one of fact. It is nowhere written that the law-fact distinction must be treated the same in 28 U.S.C. $\S 2254(\mathrm{~d})$ and in Fed.R.Civ. P. 52(a). . . . We ought to ask what is gained and what lost by appellate second-guessing of a federal district judge's determination that a state criminal defendant's confession was voluntary. ${ }^{81}$

The Court in Miller also emphasized that the fact/law distinction is not a clear or fixed determination. Rather, the Court looked to the purposes served by de novo federal court review of voluntariness. ${ }^{82}$

78 Id at 698.

7. While the proper standard for appellate review of "mixed questions of law and fact" is not clear, the Court has upheld de novo appellate review in several cases. See, for example, Bogardus v Commissioner, 302 US 34, 39 (1937) (quoting Helvering v Tex-Penn Oil Co., 300 US 481, 491 (1937)) ("[A] determination of a mixed question of law and fact ... is subject to ... review .....").

so Weidner v Thieret, 866 F2d 958, 961 (7th Cir 1989).

81 Id.

${ }^{82}$ Miller, 474 US at 114-15. 
B. Fact, Law, and Efficiency

Judge Posner's comments invite federal appellate courts to reexamine their practice of conducting de novo review of district court findings on the voluntariness of state defendants' confessions in light of the costs and benefits of such a rule. His suggestion accords with much of the Supreme Court's recent jurisprudence on the proper scope of appellate review of district court findings. Although admitting that the decision to designate an issue as one of "law" or "fact" for purposes of the proper scope of appellate review is unclear at best, ${ }^{83}$ the Court has in several recent cases looked to the effect that the designation of a finding as "law" or as "fact" would have on judicial efficiency. In Anderson v Bessemer City, ${ }^{84}$ for example, the Court reversed a Fourth Circuit decision and held that a finding of discrimination was a "finding of fact" under Rule 52(a). The Court observed:

The rationale for deference to the original finder of fact is not limited to the superiority of the trial judge's position to make determinations of credibility. . . . Duplication of the trial judge's efforts in the court of appeals would very likely contribute only negligibly to the accuracy of fact determination at a huge cost in diversion of judicial resources. In addition, the parties to a case on appeal have already been forced to concentrate their energies and resources on persuading the trial judge that their account of the facts is the correct one; requiring them to persuade three more judges at the appellate level is requiring too much. ${ }^{85}$

The Court's explicit recognition of the relevance of judicial efficiency in determining which findings should be treated as "findings of law" and which as "findings of fact" to consider judicial review of the voluntariness question from this perspective. Both parts of the voluntariness inquiry's two-pronged test-whether a defendant's will was actually overborne and whether a state's methods comply with due process-are rooted in

${ }^{83}$ See Pullman-Standard, 456 US at 288; and Miller, 474 US at 113.

84 470 US 564 (1985).

${ }^{8 s}$ Id at 574-75.

${ }^{86}$ See Miller, 474 US at 114 ("[T]he fact/law distinction at times has turned on a determination that, as a matter of the sound administration of justice, one judicial actor is better positioned than another to decide the issue in question."). 
the basic circumstances of the particular case under consideration. Requiring de novo review of this process forces the appellate courts to duplicate the efforts of the lower courts. What, if anything, would be gained by requiring courts to go through such an apparently redundant enterprise?

One response to this question is that a certain redundancy already exists within a system permitting federal review of state court decisions, ${ }^{87}$ and thus federal habeas corpus law itself sanctions a certain amount of duplicative judicial review. The answer to this argument, contained in the Court's opinion in Miller, is that the defendant has a federal constitutional right to make an unconstrained decision to confess. Consequently, the Court has allowed federal de novo review of state court findings only in instances where the federal courts possess a substantial advantage over their state court counterparts due to their familiarity with (and faithful application of) the constitutional principles that determine whether the state respected the defendant's due process rights. ${ }^{88}$ Certainly, an argument giving primary authority to the judicial actor best-suited to perform a task does not require federal appellate courts to conduct de novo review of district court findings. As courts of original jurisdiction in matters of federal law, including constitutional claims, district courts are expert in reviewing historical facts for issues of federal constitutional importance. The circuit courts do not possess any obvious advantage over the district courts in matters requiring the application of federal constitutional principles.

Indeed, unlike the district courts, which have expertise in factual determinations, the appellate courts may actually be at a disadvantage in making such determinations. In cases such as Duberstein, the Court has recognized that trial courts are better suited to conduct inquiries into an individual's state of mind and the status of individual actions under the law. ${ }^{89}$ District courts regularly establish basic historical facts and apply the law to this set of facts. ${ }^{90}$ De novo review requires the district court to conduct an

${ }^{87}$ Id at 118-19 (Rehnquist dissenting).

${ }^{88}$ Id at 117. The Court observed that while state courts have an advantage over the reviewing federal court in determining historical facts, "once ... the moment comes for determining whether ... the confession was obtained in a manner consistent with the Constitution, the state-court judge is not in an appreciably better position than the federal habeas court to make that determination."

${ }^{80}$ Duberstein, 363 US at 289-90.

${ }^{80}$ In cases arising under Title VII of the Civil Rights Act, 42 USC $\S 2000$ et seq, for example, a district court will establish the facts surrounding the allegedly discriminatory 
independent "trial" based on the state court record and any additional evidence it chooses to take. ${ }^{91}$ District courts are thus wellsuited to the task of reviewing the state court record de novo and reaching an independent finding as to the voluntariness of a confession.

For an appellate court, on the other hand, de novo review of the voluntariness of a confession represents a substantial departure from its traditional role. Constrained by the terms of Rule 52(a), federal appellate courts are largely confined to reviewing lower court "findings of law" and correcting misstatements of the law made by the lower courts in either their findings or their instructions to juries.92 This allocation of responsibility promotes judicial efficiency within the federal system ${ }^{93}$ and prevents litigants from receiving differing treatment of their claims depending on the identity of the court hearing their case. Federal appellate courts thus conserve judicial resources and enhance the uniformity of the law. Requiring appellate courts to conduct a de novo examination of the voluntariness of a confession forces them to "root about in the record" to make a factual determination, a practice outside their ordinary functions. ${ }^{94}$

Little would be gained through appellate court de novo review of the voluntariness of a confession on an appeal from a habeas corpus petition. Merely recognizing that voluntariness is an important constitutional right does not justify an additional layer of de novo review unless such review will increase the possibility of reaching the correct outcome. Although the appellate court might reverse an incorrect finding by the district court, it seems just as likely that it will err in admitting a coerced confession, or that it will mistakenly overturn a conviction by finding that the confes-

action and declare whether such facts constitute "discrimination" under Title VII.

91 The federal habeus corpus statute permits the district court to hold and "evidentiary hearing" when necessary. 28 USC § 2254(d) (1982). See also Townsend v Sain, 372 US 293 (1963).

${ }^{92}$ The chief exception to this narrow scope of review, of course, is the constitutional fact doctrine, discussed in text at notes 39-52.

${ }^{93}$ The federal court system represents a division of labor based on the principle of comparative advantage. The trial judges are better at making factual determinations, while appellate judges are better at making abstract determinations. Dividing the system into two parts enhances the accuracy of both. As one court has noted, the "main responsibility [of an appellate court] is to maintain the uniformity and coherence of the law." Mucha $v$ King, 792 F2d 602, 605-06 (7th Cir 1986).

${ }^{94}$ See Sotelo, 850 F2d at 1254 (Easterbrook concurring) ("[R]equiring three appellate judges to root about in the record and come up with their independent characterizations and inferences ... asks of them what they do least well, while diverting time from functions at the core of their duties."). 
sion was coerced when it was in reality freely given. Indeed, after de novo consideration of the record surrounding the confession, the district court and appellate courts may come to equally defensible, but opposing viewpoints. ${ }^{95}$ In the absence of any special expertise that would justify independent review, de novo review by the appellate court appears to add nothing except the time of three more judicial actors who could just as likely reach the wrong result as the district court judge.

A more appropriate function for the appellate courts in reviewing habeas corpus petitions would be to ensure that the standards used by the lower courts are correct and uniform throughout the circuit. Thus, a circuit court must ensure that the district court finding on voluntariness did not look into the state of mind of the petitioner alone, but also examined the methods employed by law enforcement officials. If not, the circirit court should remand the case to the district court with instructions to consider the methods used by the state to extract the confession..$^{96}$ Additionally, the circuit courts retain their ability to review and reverse district court findings of fact that are "clearly erroneous." Thus, if the evidence clearly demonstrates that the state's methods for extracting the defendant's confession overwhelmed his will, and yet the district court found otherwise, the circuit court should reverse..$^{97}$ By focusing their attention on questions of law, the circuit courts can simultaneously fulfill their proper role within the federal judiciary and promote a more efficient judicial system.

C. Congressional Recognition of the Importance of Efficiency in Habeas Corpus Proceedings

The discussion thus far has suggested that plenary appellate review of the voluntariness question is neither mandated nor useful in direct appeals or in habeas cases. In Miller, the Court expressed a need for plenary federal review of the voluntariness issue

${ }^{95}$ The Court has noted that there is little to be gained by de novo review of a set of facts that permit two defensible readings. Anderson, $470 \mathrm{US}$ at 573-74. See also United States $v$ Yellow Cab Co., 338 US 338, 342 (1949).

${ }^{98}$ See Kelly $v$ Southern Pacific Co., 419 US 318, 331-32 (1974) (the proper role of the circuit courts when the district court applies an incorrect legal standard is to remand for a re-examination of the record in light of the proper legal standard). See also Pullman-Standard, 456 US at 287.

${ }^{97}$ See, for example, Davis v North Carolina, 384 US 737 (1966) (oral and written confession ruled inadmissible where the defendant, a poor man with a fourth grade education, was interrogated over a period of 16 days without any notification of his rights, and was informed that he had no right to use the telephone or see anyone). 
in habeas cases. Once this need is satisfied by proper district court de novo review, the appellate court should use standard Rule 52(a) analysis to determine whether it, too, should review the question de novo. As part of this analysis, the court should recognize that stronger reasons exist in the habeas context than in direct appeals to refrain from conducting de novo appellate review. In addition to the obvious duplication of both the district and state courts' efforts, the appellate court should consider the intent behind Congress's most recent amendment to the Habeas Corpus Act limiting the power of federal courts to review findings of fact by the state courts.

The 1966 amendment, which limited federal court discretion to disturb state court findings in habeas proceedings, appears to have been driven by legislative and judicial recognition that the number of applications by state prisoners for writs of habeas corpus had been increasing at an extremely rapid pace. ${ }^{98}$ Comment on the legislation is scarce, but there are indications that Congress intended to make federal court review of habeas corpus petitions more efficient. Judge Orie Phillips of the Tenth Circuit, then Chairman of the Judicial Conference Habeas Corpus Committee, observed: "The purpose of [the legislation] ... is to prevent the abuse of the writ of habeas corpus by persons in custody under judgments of State courts ... ." This objective accorded with the Supreme Court's stated desire to prevent habeas corpus proceedings from "swamp[ing] the dockets of the District Courts."100

The amendment seems to have slowed the growth in the number of habeas corpus petitions filed by state prisoners in the district courts. ${ }^{101}$ But if Congress thereby eased the district courts' burden, it did not slow the rise in the number of appeals from these district court decisions filed in the circuit courts. From 1977 to 1982 , the number of appeals of district court decisions in habeas corpus proceedings grew from 712 to 1529 , a. 114.7 percent increase. ${ }^{102}$

${ }^{98}$ The number of applications received by the district courts had risen dramatically in the three years prior to passage of the 1966 amendment, from approximately 1700 applications in 1963 to well over 3200 in 1964, and more than 4800 in 1965. Habeas Corpus-State Custody, S Rep No 89-1797, 89th Cong, 2d Sess 1 (1966).

99 Id at 4.

${ }^{100}$ Townsend, 372 US at 319.

${ }^{01}$ Although no research has correlated the two events, the number of habeas filings by state prisoners levelled off in the late 1960s and early 1970s. See Department of Justice, Federal Review of State Prisoner Petitions: Habeas Corpus 2 (1984).

${ }^{102}$ Id at 4. Statistical data further shows that over 26 percent of all state prisoner habeas corpus cases filed in district court were appealed to the federal circuit courts, with 
Accompanying this rise in the number of appeals of district court habeas corpus decisions has been an increase in the level of judicial resources needed to process these appeals. ${ }^{103}$ Yet, at a time when limited judicial resources must accommodate an ever greater number of appeals, the federal appellate courts have bound themselves to conduct de novo review of the voluntariness of a defendant's confession whenever the defendant alleges that it was obtained involuntarily. This review duplicates the efforts undertaken by both the state courts and the federal district court.

Because most habeas corpus petitions contain multiple allegations of illegal imprisonment, it is somewhat difficult to accurately determine the number of habeas corpus petitions based on allegedly involuntary confessions. What little data there is suggests that just over five percent of all habeas corpus petitions filed in the district courts contain claims of allegedly involuntary confessions. ${ }^{104}$ One might argue that if involuntary confession claims account for such a small percentage of the overall number of claims in habeas corpus petitions, the "wasted" judicial resources resulting from de novo appellate review is inconsequential.

Yet the de novo review that the circuit courts conduct requires an examination of both the district court record and the state trial court record to determine whether the confession at issue was indeed voluntary. The process is essentially a "re-trial" of the voluntariness question based upon the appellate court's own examination of the record. Thus, de novo review requires a substantial expenditure of judicial resources in each particular case. Moreover, no expenditure of judicial resources is inconsequential when both the federal district and appellate courts are "already heavily burdened."105

an average period of 10.4 months between filing a notice of appeal and the appellate court decision. Id at 7. For a general statistical survey of habeas corpus state prisoner petitions, see Paul H. Robinson, An Empirical Study of Federal Habeas Corpus Review of State Court Judgments (DOJ, 1979).

${ }^{103}$ Justice Department statistics show that a growing backlog of habeas corpus cases exists in the appellate courts. The Justice Department offers no explanation for this in crease. See Department of Justice, Federal Review of State Prisoner Petitions at 7 (cited in note 101).

104 Robinson, An Empirical Study of Federal Habeas Corpus at 12 (cited in note 102).

${ }^{005}$ United States v Peltier, 422 US 531, 560 (1975) (Brennan dissenting). For other statements concerning the growing burden on the federal system, see American Law Institute, Proceedings of the 49th Annual Meeting 25-27 (1972) (opening remarks of former Chief Justice Warren E. Burger); and Warren E. Burger, Annual Report on the State of the Judiciary 5 (American Bar Association, 1980). 
In adopting the 1966 amendments, Congress understood the importance of judicial efficiency in reviewing habeas corpus petitions. Congress recognized that although habeas corpus was essential for the protection of federal rights, it could not be allowed to overwhelm the federal court system. ${ }^{106}$ Miller was silent on the issue of the appropriate standard of federal appellate court review of the voluntariness of confessions, leaving the circuit courts without a clear mandate. In the absence of such a mandate, and given the Court's explicit recognition that it is appropriate to consider the efficient allocation of judicial resources in determining the proper standard of review under Rule 52(a), ${ }^{107}$ the appellate courts should acknowledge Congress's emphasis on judicial efficiency. Such emphasis provides a clear standard of deference for federal appellate review of district court findings on the voluntariness of confessions.

\section{ConClusion}

The circuit courts of appeals have bound themselves to conducting de novo review of district court findings on the voluntariness of a confession in habeas corpus proceedings. The unanimity of the circuit courts is not simple wrong-headedness, but rather a reasonable interpretation of both the Supreme Court habeas corpus decisions and its inconsistent holdings on the proper scope of federal appellate review of factual determinations that involve constitutional issues. Yet, in the absence of any statutory directive or Supreme Court decision to the contrary, the circuit courts of appeals remain free to re-evaluate their current position. For several reasons, it would be wise for them to do so.

As the Court has noted, the decision as to the proper standard of appellate review of lower court findings "has turned on a determination that, as a matter of the sound administration of justice, one judicial actor is better positioned than another to decide the issue in question." 108 It is precisely concern for the "sound administration of justice," both in terms of simple efficiency and ensuring that the judicial actor best suited to ascertaining facts and determining individual legal rights has the authority to do so, that point in the direction of giving the district court primary responsi-

106 See S Rep No 89-1797 at 1-2 (cited in note 98) ("The number of applications by State prisoners for writs of habeas corpus has been steadily increasing . . . . [T] tions in their totality have imposed a heavy burden on the Federal courts."). See also Townsend, 372 US at 319 ("[T]he too promiscuous grant of evidentiary hearings on habeas could . . . swamp [district court] dockets . . . .").

${ }^{107}$ See Anderson, 470 US at 574-75; and Miller, 474 US at 114.

108 Miller, 474 US at 114. 
bility for voluntariness decisions in a habeas corpus proceeding. By adopting the "clearly erroneous" standard, the circuit courts could abandon a rule that ignores the growing burden of habeas corpus appeals, strong congressional concerns for promoting efficient consideration of habeas corpus petitions, and clear advantages in judicial efficiency. It is a change that circuit courts cannot and should not rely on the Supreme Court to make for them. 
